\title{
4 \\ Is the CETA a Road Map for Australia and the EU?
}

\author{
Annmarie Elijah
}

\section{Introduction}

Canada and the European Union (EU) reached agreement on key aspects of the Comprehensive Economic and Trade Agreement (CETA) in October 2013. The full text was released to the public in September 2014 before undergoing a legal 'scrub' ahead of ratification across the jurisdictions. The CETA was signed in October 2016 and approved by the European Parliament in February 2017.

For the EU the CETA is the first trade agreement with a Group of Eight (G8) country and a significant plank in its post-2006 'Global Europe' trade strategy, which moved the focus of EU trade policy towards bilateral deals. For Canada it represents an attempt to cement political and economic ties with the EU and diversify its trade profile, which is otherwise heavily dominated by the United States of America (USA).

In a joint statement at the time of its release, the EU and Canada referred to the CETA as an 'ambitious and ground-breaking' agreement. It is a complex and lengthy text that took almost five years to negotiate. The agreement is a good example of the 'new generation' of trade agreements that seek to address both traditional market access issues and 'behind the border' impediments to trade. 
The CETA includes chapters on market access; rules of origin; trade remedies; technical barriers to trade; sanitary and phytosanitary measures; customs and trade facilitation; subsidies; investment; cross-border trade in services; temporary entry; mutual recognition of professional qualifications; domestic regulation; financial services; international maritime transport services; telecommunications; electronic commerce; competition policy; state enterprises; monopolies and enterprises; government procurement; intellectual property; sustainable development; labour; the environment; and regulatory cooperation.

It includes protocols on conformity and manufacturing practices and a number of joint declarations and understandings, some of which serve to incorporate former agreements into the new framework. Multiple annexes set out reservations to the agreement. It contains robust administrative and institutional provisions and sets out the parameters for dialogue and further bilateral cooperation between the EU and Canada. It thus constitutes a 'living agreement' in the sense that obligations among the parties may be expected to change in coming years.

The starting question for this chapter was whether the CETA might constitute a 'road map' for a possible trade agreement between Australia and the EU, with particular reference to the role of sub-national governments; mutual recognition of qualifications; government procurement; and institutional provisions. The chapter proceeds with a history and context, before outlining findings in the specific areas, and drawing lessons for Australia. With some important qualifications, the research confirms the usefulness of the CETA as a recent indicator of the EU's likely position in any forthcoming negotiations. The concluding section argues that the CETA provides grounds for cautious optimism about prospects for an Australia-EU agreement, noting the different context of the bilateral relationships.

\section{History and context}

Notwithstanding some clear historical parallels in the bilateral relationships, a survey of existing political and economic cooperation between Canada and the EU compared with Australia and the EU reveals a 'thicker' transatlantic relationship. Canada has a longer and stronger record of cooperative action with the EU, including a less acrimonious trading relationship since establishment and more cooperative agreements 
in place. In the postwar years, economic ties with European countries waned in favour of strong Canada-USA ties (Deblock \& Rioux 2010). Canada did, however, maintain significant member state relationships with both the United Kingdom and France, a fact that became relevant in the trade negotiations.

The formal history of the CETA commenced in 2007 at the Canada-EU Summit in Berlin when the parties announced that joint work would be undertaken on the potential benefits of an agreement. However, a CanadaEU trade agreement was debated and even pursued much earlier. There was an attempt to institutionalise economic cooperation in the late $1990 \mathrm{~s}$ with the EU-Canada Trade Initiative. In the early 2000s, a parliamentary report suggested a trade agreement to address the 'steady downward spiral' of Canada-Europe economic relations (see especially Dymond \& Hart 2002) and Prime Minister Jean Chrétien was instrumental in launching the Trade and Investment Enhancement Agreement (2002). There was little enthusiasm on the EU side, however, with the main emphasis still on multilateral trade negotiations at that time (Hage 2011). Canada-EU economic cooperation remained largely superficial.

In Canada, the debate over enhanced ties with the EU is always conducted with reference to the concentration of trade with the USA: the EU is necessarily cast as an 'alternative' partner, and in some cases a solution to 'stagnating' North American economic integration (DeBardeleben \& Leblond 2010). However, Canada has faced difficulties in terms of leverage. Although political and economic ties between the EU and Canada were sound, for many years Canada 'did not constitute a priority for Europe' (Deblock \& Rioux 2010).

In the event, it was a provincial premier who raised the political profile of a possible trade agreement in both Canada and the EU. Arguably, Quebec Premier Jean Charest was uniquely placed in this regard. His work in championing an agreement at home and abroad (including with the French Council presidency of 2008) coincided with extremely slow progress multilaterally and a changed set of EU trade policy priorities (Hage 2011). After a joint study that promised benefits in both the EU and Canada, the negotiations were formally launched in May 2009.

Like other potential trade agreement partners for the EU, Canada was obliged to put in train a treaty-level political agreement in tandem with the economic negotiations. The Strategic Partnership Agreement was 
concluded in 2014. The form of wording in the agreement includes a satisfactory outcome on the so-called linkage issue, whereby agreements with the EU are connected with each other and subject to human rights clauses. The wording had previously caused consternation over the EU's political agreements with Canada, Australia and New Zealand.

The CETA negotiations took five years, not including the 'scoping' period preceding the formal launch in 2009 or the legal scrub, multiple translations and ratification currently underway. The time that would be required to complete the CETA was repeatedly underestimated by analysts and governments throughout the negotiations (see, for example, Deblock \& Rioux 2010: 39) and few anticipated the EU's internal political difficulties of October 2016 when the government of the Belgian region of Wallonia threatened to veto the CETA immediately prior to its signature.

At the completion of the CETA text, the agreement was recognised by the EU and Canada as a new phase in bilateral relations and 'a vehicle to create new prosperity' on both sides of the Atlantic (Government of Canada \& European Union 2014). In terms of traditional market access the CETA results in clear gains for both parties, with liberalisation (tariff reductions and quota increases) occurring upon entry into force and at three, five and seven years thereafter. The European Commission describes the elimination of customs duties for goods originating in the EU and Canada as applying to 'almost all goods' (European Commission 2014a). Carve outs (exclusions and longer transitional arrangements) remain in sensitive areas.

In relation to services and investment, the CETA 'constitutes the most comprehensive trade agreement the EU has ever concluded' (European Commission 2014a). Given that the projected gains from the agreement rely heavily on trade in services, this is significant. The chapters relevant to trade in services are numerous and not all aspects are covered here. A key point is that the EU was persuaded to enter into a 'negative list' for services, widely regarded as being a more liberalising instrument, since parties are required to list reservations and exceptions and include all other trade.

The way this has been handled in the CETA is a complex two-tiered system of annexes. Annex I lists existing measures and restrictions that parties wish to maintain, with no other restrictions to apply and 'no risk of rollback' (European Commission 2014a). This is considered especially 
important to provide certainty to business. Annex II lists further measures but makes no commitment on whether parties will adopt new, different or potentially more restrictive measures in the future. The annexes on services run to more than 300 pages. The full implications of the CETA and its treatment of trade in services will not be known for some time.

\section{The role of sub-national entities}

Negotiations for the CETA were genuinely 'multilevel'. While the interests of the EU's member states (and for that matter its sub-national entities) were represented by the European Commission, the Canadian provinces and territories were directly involved in the negotiations. This was the first—and so far only_time that the provinces were 'at the table' for a trade deal. ${ }^{1}$ This involvement was at the request of the EU, which sought 'buy-in' at a sub-national level (Fafard \& Leblond 2013).

Projected gains from the CETA are substantially attributed to 'behind borders' liberalising measures. The changed nature of trade agreementsoften referred to as 'second generation' agreements- has involved subnational entities more than previously, as issues under negotiation impact on policy competences not held exclusively at the national level.

The need for province and territory commitment to the CETA was most obvious in relation to government procurement, but sub-national involvement was by no means limited to Chapter 19. It was estimated in 2012 that the provinces and territories were actively involved in more than half of the negotiating committees on the CETA (Fafard $\&$ Leblond 2012). Further, as negotiations progressed it was clear that different regions stood to gain (or lose) to different degrees from the proposed deal. The negotiations underlined the need for effective coordination among the Canadian provinces and territories and with the federal government, which has the authority to negotiate, sign and ratify international treaties.

1 This negotiating model has not been replicated in other trade negotiations that Canada has since commenced; for example, the Trans-Pacific Partnership (TPP) negotiations, which Canada formally joined in October 2012. 
This is not to suggest that the CETA was the first time that Canadian provinces and territories were involved in international negotiations. Consultation and information-sharing mechanisms had existed since the negotiations of the (then) Canada-USA Free Trade Agreement (1989) and later the North American Free Trade Agreement (NAFTA). Established 'C-Trade' meetings took place quarterly and more often as appropriate. Existing coordination mechanisms, however, were challenged by the CETA. Proponents of the deal—such as the former Premier of Quebec, who saw himself as a key player-sought additional involvement. Other provinces and territories were vocal in their opposition. Particularly where provincial interests did not align with likely outcomes, the difficulty of maintaining 'one voice' was an ongoing challenge for the Canadian government.

Notwithstanding the difficulties, the Canadian rationale for including the provinces and territories in the negotiations may have been twofold. First, it met the need to assure the EU of provincial commitment to the agreement. Second, it served as a neat precursor to the domestic reforms that will need to occur to implement the CETA—some of which are long overdue. Here the recognition of occupations and professions is a good example, where domestic impediments to movement across provinces has become a significant problem. In this case, the CETA has provided impetus to a domestic reform process.

Since the CETA's conclusion and its release in September 2014, the complex nature of provincial commitment to the agreement has become publicly apparent. Based on a dispute over compensation for fisheries, Newfoundland has first, threatened to withdraw support for the CETA and second, raised its concerns directly with EU institutions and the member states. This is notwithstanding considerable effort on the part of the Canadian Government to maintain a unified negotiating position and adequate buy-in from provinces and territories. It is unclear whether these late objections will have any impact on implementation of the agreement. In the event, it was the role of EU sub-national entities that proved politically salient immediately prior to the CETA's signature in late 2016. 


\section{Mutual recognition of professional qualifications}

A stated objective of the CETA is to increase the flow of professionals between the EU and Canada. Chapter 10 (temporary entry) clarifies and simplifies provisions relating to short-term business visitors with the aim of facilitating trade and investment. It includes the aim of visa-free travel for EU and Canadian citizens in the near future (Government of Canada \& European Union 2016).

Provisions for mutual recognition of professional qualifications appear in Chapter 11 and a related annex. The European Commission DirectorateGeneral for Trade's assessment of this chapter is that the CETA has 'broken new ground' (European Commission 2014a). The institutional innovation here is to enable relevant authorities and professional bodies in the jurisdictions to work with government in establishing a mutual recognition agreement (MRA) in a given area.

The chapter establishes a joint committee that will oversee cooperation on the recognition of qualifications. The committee will assess proposals on the basis of criteria including industry needs, potential economic benefit, and compatibility of licensing and qualifications requirements for that sector before a sector-specific MRA is signed and implemented. These provisions are potentially liberalising but must be seen as a starting point for a forthcoming, potentially lengthy, process of assessment across different sectors.

Ultimately, when specific MRAs are concluded, EU professionals would have their qualifications recognised in Canada, and vice versa. Much may depend on relevant authorities or professional bodies driving the process. In some cases professional bodies appear to have begun their work in anticipation of institutional mechanisms that would enable mutual recognition. Engineers and architects are apparently advanced in negotiations, and in these cases the measures will most likely prove successful in enabling people movement.

In other areas sustained attention to implementation and uptake will be required to make best use of the measures. This can best be described as a cautious or 'managed' form of mutual recognition that will be applied 
on a case-by-case basis. ${ }^{2}$ Economic gains from mutual recognition provisions in the CETA may therefore be limited in the short term. The Joint Committee on Mutual Recognition will meet within a year of the entry into force of the CETA and report back to the CETA committee on progress in relation to MRAs. Built-in transparency provisions (Article 11.5(e)) should enable progress on MRAs to be monitored.

\section{Government procurement}

The European Commission summary of the CETA states that the EU achieved 'a very positive result, fully in line with the EU interests and negotiation requests' on government procurement (European Commission 2014a). The provisions of Chapter 19 refer to reciprocal bidding rights inside the $\mathrm{EU}$ member states and the Canadian provinces and territories. This may include federal entities, provincial and territorial ministries, most agencies of government, crown corporations, regional, local and municipal governments and entities.

Certain thresholds and exemptions remain in place to address provincial interests, for smaller contracts and non-urban areas in Canada. ${ }^{3}$ However, Chapter 19 is seen by the EU as a significant win in terms of access, particularly in relation to municipalities, academic, school boards and hospitals (known as MASH), which have not previously been included in any Canadian trade agreement. According to the Directorate-General for Trade the 'opening to European bidders is unprecedented' (European Commission 2014a).

The CETA text on government procurement is compatible withand indeed derived from-the World Trade Organization's (WTO) Agreement on Government Procurement (GPA), a plurilateral agreement aiming to ensure fairness and transparent conditions of competition on procurement. Signatories commit to the GPA with schedules detailing market access. In the revised GPA (finalised in April 2014) the parties undertook to revisit the agreement and negotiate on extended coverage within three years. WTO dispute resolution mechanisms

2 These provisions in no way resemble the mutual recognition provisions implemented by Australia and New Zealand in the 1990s. In that case all registered occupations (except medical practitioners) were deemed mutually recognised among Australian jurisdictions and New Zealand upon entry into force of the agreement. See the Trans-Tasman Mutual Recognition Arrangement (1998).

3 For example, exceptions were made for some energy suppliers in Ontario and Quebec. 
apply to the GPA. The CETA further builds on GPA commitments by institutionalising Canada-EU cooperation through a government procurement committee, which will report to the CETA committee.

Importantly, Canada has committed to a level of openness in the CETA that it did not in the GPA context. While both the EU and Canada are signatories to the GPA, the EU has committed to coverage across central, sub-central and 'other entities'. Canada committed only to coverage at the level of central government. On the basis of lack of reciprocity, the EU did not extend access to procurement to Canada under its GPA commitments. The 2008 joint study commissioned by the Canadian Government and the Directorate-General for Trade estimated that only 10 per cent of procurement in the EU and Canada was subject to any GPA commitments at that time (European Commission \& Government of Canada 2008).

Thus, the benefits from Chapter 19 accrue to both European and Canadian companies, which will upon ratification have unprecedented access to procurement across levels of government, with certain exceptions. For obvious reasons, the ongoing commitment of sub-national entities in both Canada and the EU will be crucial to successful implementation of the procurement measures. This goes some way to explaining the EU's enthusiasm for having Canadian provinces and territories 'at the table' for the negotiations.

On close inspection, the procurement situation inside the EU is also complex. Notwithstanding claims from the European Commission about the EU being substantially open to outside bidders already, analysts have recently highlighted the inadequacy of procurement data internationally. This makes claims about openness difficult (if not impossible) to substantiate. The CETA does include transparency provisions (Article 19.19) requiring the collation of statistics and that parties report annually to the committee, which may help in time to understand procurement in the bilateral relationship.

Researchers also found in 2012 that openness varied significantly across EU member states, and that there may be non-tariff barriers (NTBs) at work in procurement in both the internal market and for foreign suppliers (Messerlin \& Miroudet 2012a, 2012b). This issue was also highlighted in the annual US report on trade barriers, which newly singled out Poland and Slovakia, and identified further issues in countries listed previously, 
such as the Czech Republic, France, Italy and Romania. US trade negotiators have pointed to issues ranging from widespread corruption to transparency issues, inadequate law enforcement and inefficiencies in government as trade barriers (Inside US Trade, 8 April 2015). Procurement has been a vexed issue in the EU-USA negotiations for a Transatlantic Trade and Investment Partnership (TTIP).

It is worth noting that government procurement across the EU single market is a work in progress, with a recent law reform taking place in 2014 and still being implemented across the member states. For the moment it is safe for trade partners and foreign bidders to assume that the 28 member states (EU28) are not all equally accessible in terms of procurement.

\section{Institutional provisions}

Institutional provisions governing how the CETA will work are found predominantly in Chapter 26 (administrative and institutional provisions). These are straightforward and complement existing mechanisms for bilateral dialogue. The CETA Trade Committee will oversee a number of specific committees tasked with monitoring chapters of the agreement (for example, on mutual recognition and government procurement). Dispute settlement mechanisms (Chapter 29) provide for consultation, mediation and intergovernmental bargaining among the parties should differences of opinion arise. These exist alongside existing recourse to the WTO but aim to resolve issues much faster. In general, the institutional provisions for the CETA are robust. Given that much work remains to be done-for example, in working together on closer regulatory regimes, and finalising MRAs - it is imperative that the CETA is a 'living agreement'. Progress in bringing Canada and the EU economically closer will depend greatly on the effectiveness of these committees.

Strong review mechanisms no doubt reflect EU and Canadian intentions to fully implement the CETA. The mechanisms also reflect the fact that neither party yet knows the outcomes of the TTIP during negotiations. An indicative example can be found in Chapter 4 on technical barriers to trade, which has an annex entitled 'Cooperation in the field of motor vehicle regulations'. Annex 4-A of the annex is a revision clause that enables the parties to revisit the terms of the deal relating to motor vehicle regulations, in a long-standing area of disagreement between the EU and 
the USA. It is entirely possible that aspects of the CETA could be refined or reviewed if the TTIP were to proceed in some form. Institutional provisions reflect this.

Bilateral negotiations between Canada and the EU on a Strategic Partnership Agreement were conducted in tandem with the CETA negotiations and concluded in September 2014. The agreement aims to enhance bilateral cooperation on a broad range of issues.

The Strategic Partnership Agreement is relevant here in that it contains provisions relating to the 'linkage issue', which arises in EU agreements. The linkage clauses knit together bilateral agreements between a third country and the EU. Further, at the insistence of the European Parliament, framework and partnership agreements with the EU necessarily contain clauses relating to human rights. The upshot of the linkage clauses and the human rights inclusions is that in the event of a breach by a partner government, the EU could effectively suspend all bilateral agreements with that partner, including trade and economic agreements. Among developed economies this is considered an unlikely event; nevertheless, the clauses have been a sticking point in agreements with a number of countries negotiating with the EU, including Canada, Australia and New Zealand. The form of words agreed in the SPA has effectively provided an institutional workaround for this longstanding irritant.

An aspect of the CETA that has not yet been explored in any detail is the implications of the agreement for third countries. These will be most apparent in relation to the USA to the extent that the CETA impinges on North American economic integration. However, the third country implications will not be limited to the USA. Institutional provisions include a joint declaration (Chapter 30) towards the end of the CETA text, which encourages Canada to begin negotiations as soon as possible with countries who have an existing customs union with the EU and 'whose products do not benefit from the tariff concessions under this Agreement' (European Union \& Government of Canada 2016). Canada may need to add further trade deals to its current negotiating list. 


\section{Implications for Australia}

Preliminary work on a possible Australia-EU trade agreement is being undertaken in both Canberra and Brussels. However, the case for such an agreement is still being made. Current indications are that the agreement will be launched in late 2017. In this context, the final terms of the CETA take on particular relevance for Australia.

Kenyon and van der Eng have previously established the economic comparability of Canada and Australia in terms of suitability for an EU trade agreement (Kenyon \& van der Eng 2014). ${ }^{4}$ Adams et al. concur, noting that the two share 'substantial economies, similar economic structures and similar trade profiles with the EU' (Adams, Brown \& Wickes 2013). Without rehearsing this argument in full, if anything, this case has recently strengthened. Canada remains the larger economy, but the gap has narrowed.

The two countries' top 10 export commodities continue to bear a striking resemblance. Trade in services-and the EU's role in that sectorremains crucially important to both economies. Total services trade has been growing, basically doubling in value between 2000 and 2012 for both countries (UN Comtrade 2015a, 2015b). Canada is rated 22nd in the most recent Ease of Doing Business Survey and Australia is rated 15th (World Bank 2016). Recent figures confirm that investment is the strongest dimension of the economic relationship for both Canada and Australia (see especially EU Delegation to Australia 2016).

A key difference in the trade profiles between the two countries is the relative diversity of the Australian economy. Merchandise exports are moderately concentrated among partners for Australia, with the top nine partners accounting for 80 per cent or more of exports in 2013. Exports are described as highly concentrated among partners for Canada, with the USA accounting for almost 75 per cent of Canadian exports in 2013. Australian imports are even more diversified whereas Canadian imports are also concentrated (UN Comtrade 2015a, 2015b). The importance of the USA to the Canadian economy can hardly be overstated, and this alters the context of Canada's trade negotiations significantly.

4 See especially Table 2 on page 236, which sets out a comparison of economic indicators. 
The history of Australian-EU relations also differs in important respects to Canadian-EU relations. Australia and Canada have achieved a similar set of cooperative agreements with the EU, although Canada has often been ahead. It was the first country to achieve an agreement with Euratom (1959) and the first industrialised country to arrive at a Framework Agreement on Economic Cooperation (1976). It can be no surprise that Canada was regarded by the $\mathrm{EU}$ as a suitable candidate for comprehensive trade negotiations.

With these issues in mind and drawing on analysis of the CETA in the chapters outlined above, this section begins to draw out the possible implications for Australia in any forthcoming negotiation with the EU. In general terms, the CETA does provide some clues for Australia: it confirms, for example, that enhanced market access to the EU is possible in sectors such as agriculture, and that the EU would bring to the negotiating table a high level of ambition in relation to 'behind borders' measures.

\section{The role of sub-national entities}

The CETA raised unprecedented issues relating to the involvement of Canadian provinces and territories in trade agreements. While there are important differences in the functioning of the Canadian and Australian federations, it is clear that an Australia-EU agreement would raise many of these same issues.

The first set of questions for Australia are about whether the EU would seek state and territory representation at the negotiations, and whether the Australian Government would accept this. Either way, the states and territories (and perhaps even local governments) would need to be involved in some form, and the importance of early and effective engagement on a possible agreement can hardly be overstated. This engagement would need to go beyond consultation to secure political commitment and ensure successful ratification and implementation. It is worth noting that the entire process may take some years. Further, if the EU was assured of successful Australian internal coordination on trade policy, the perceived need for direct involvement in the negotiations could perhaps be overcome. As negotiations progress, the Australian Government will need to be prepared to give specific details of how the proposed trade 
agreement will benefit Australian states and territories, ${ }^{5}$ and how any negative implications will be dealt with. In the Canadian case, this meant federal government compensation in some sectors to secure provincial agreement.

\section{Mutual recognition of professional qualifications}

Specifically in relation to the provisions on mutual recognition of professional qualifications, the CETA measures in their current form constitute no obvious difficulty for the Australian Government. The question here is whether a higher level of ambition would be warranted, rather than case-by-case painstaking construction of specific MRAs by sector. If the CETA provisions were replicated for Australia, it is likely that well-organised industry and/or professional bodies would be able to pursue mutual recognition in specific instances to good effect. It may take some time. On the other hand, in sectors where there has already been significant domestic and/or trans-Tasman efforts made, mutual recognition could potentially proceed faster.

\section{Government procurement}

On government procurement it is safe to assume that the EU would bring the same or similar negotiating requests to the table in the first instance, and that increased access would be pursued aggressively. The European Commission has stated that their demands were successful in the CETA (European Commission 2014a). This same ask would place new demands on Australian authorities.

In the event that the Australian Government proceeds with plans to move from observer status to a member of the GPA (The Hon Andrew Robb AO MP, Minister for Trade and Investment, 2014) EU expectations could potentially line up with current Australian policy intentions in this sector. Recent changes to the GPA (2014) appear to be better aligned with Australian policy objectives.

The openness and barriers in the Australian procurement market are well summarised in recent WTO reviews. Recent European Commission reports on potentially trade-restrictive measures identify certain Australian procurement policies (at federal and state levels) as problematic

5 See the Canadian Government's breakdown of benefits by jurisdiction at www.international.gc.ca. 
(European Commission 2013, 2014b). The Buy Australian at Home and Abroad and the Plan for Australian Jobs packages both feature, as do minimum local content targets, 'buy local' campaigns, and small and medium enterprises measures. These issues are likely to be raised in negotiations.

Negotiations on government procurement would also draw attention to new opportunities inside the EU market for Australian companies. As outlined above, existing research shows that sound data around government procurement is scarce. Claims about the openness of the EU market should be carefully evaluated across the 28 member states. Claims that GPA membership (and commitments across all levels of government therein) somehow equate to open procurement markets should also be scrutinised.

The procurement issue places state and territory involvement front and centre in any negotiations, and has the potential to raise the political profile of a potential agreement. One critical report argues that the CETA:

will substantially restrict the vast majority of provincial and municipal government bodies from using public spending as a catalyst for achieving other societal goals (Sinclair, Trew \& Mertins-Kirkwood 2014).

The issue of 'green procurement' also came to the fore in the course of the negotiations (Hubner 2010). Similar political sensitivities can be expected in the Australian context.

\section{Institutional provisions}

On the face of it, the institutional provisions present no special problem for the Australian Government. Robust review mechanisms and the prospect of a 'living agreement' are consistent with the approach taken in other bilateral deals. The principal institutional impediment to an Australia-EU trade deal was the incomplete framework agreement, which is now finalised.

\section{Conclusions}

So, is the CETA a 'road map' for Australia and the EU as a trade agreement, as canvassed in Canberra and Brussels? The answer is yes, and no. In many ways the CETA provides a suitable comparison for any agreement between 
Australia and the EU. In the CETA, Canada and the EU were able to secure increased market access and progress a raft of 'behind the border' measures. Australia and Canada are similarly attractive as trade partners for the EU, and the two countries face similar asymmetrical difficulties in dealing with the EU28.

In the CETA chapters examined in detail here, the agreement is an excellent guide as to what the Australian Government could expect in a negotiation. An optimistic assessment might conclude that an AustraliaEU agreement would yield a negative listing for trade in services (with significant reservations); improved access to government procurement markets for both parties; managed mutual recognition provisions on qualifications leading to greater people movement; and a set of institutional provisions enabling long-term economic cooperation to flourish. Impact on the states and territories would be significant, in a range of areas.

Yet, offensive and defensive interests in a trade negotiation are unique to each bilateral relationship, and outcomes will differ. Australia and the EU have a more troubled, less institutionalised, history. Canada and Australia operate in different regional contexts and have adapted accordingly. The overwhelming importance of the USA in Canada's trade profile cannot be overlooked. Considering the EU's stated intention to negotiate a comprehensive trade deal with the USA, it is impossible to escape the conclusion that both parties conducted the CETA negotiations with one eye on the TTIP. It is clear that the TTIP and the CETA are connected from the EU perspective. Prospects for the TTIP's conclusion are presently poor, and the internal EU controversy relating to CETA has not helped.

This dynamic is not at work in the Australian case, and it changes the negotiating context significantly. The EU arguably has a 'defensive interest' in a trade agreement with Australia because of the Trans-Pacific Partnership (TPP) negotiations (Adams, Brown \& Wickes 2013), but this may not raise Australia as a priority for the EU—in terms of starting negotiations, or successfully completing them. Bauer et al. have argued that the EU should seek to address the 'blind spot' of Australia and New Zealand to advance its priorities in the Asia-Pacific, and there is a case to be made for this approach (Bauer et al. 2014).

The timing of negotiations also matters a great deal, especially on traditional market access issues. Adams, Brown and Wickes pointed out in 2013 that if the TTIP suddenly progressed the USA could 'strip 
the EU's cupboard bare' on agriculture in particular (Adams, Brown $\&$ Wickes 2013). A transatlantic deal looks increasingly unlikely, however the progress of other trade deals, and their implications for Australian trade with the EU has not escaped the attention of Australian exporters (Condon 2014). The advancement (or otherwise) of the mega-regionals may therefore impact prospects for an Australia-EU agreement.

\section{References}

Adams, Mike, Nicolas Brown \& Ron Wickes (2013), Trading Nation: Advancing Australia's Interests in World Markets (UNSW Press: Sydney).

Bauer, Matthias, Fredrick Erixon, Martina Ferracane \& Hosuk LeeMakiyama (2014), 'Trans-Pacific Partnership: A challenge to Europe', ECIPE Policy Brief, no. 9/2014.

Condon, Jon (2014), 'BeefEx: Are There Risks Ahead for Australia's Grainfed Beef Access to the EU?', Beef Central, 23 October. Available at www.beefcentral.com/features/beefex-2014/are-there-risks-aheadfor-australias-grainfed-beef-access-to-the-eu/.

DeBardeleben, Joan \& Patrick Leblond (2010), 'The other transatlantic relationship: Canada, the EU, and 21st-century challenges', International Journal 66(1): 1-7. doi.org/10.1177/ 002070201106600101.

Deblock, Christian \& Michèle Rioux (2010), 'From economic dialogue to CETA: Canada's trade relations with the European Union'. International Journal 66(1): 39-56. doi.org/10.1177/ 002070201106600104 .

Dymond, William \& Michael Hart (2002), 'A Canada-E.U. FTA is an awful idea', Policy Options Politiques, 1 July. Available at policyoptions. irpp.org/issues/public-policy-2002/a-canada-eu-fta-is-an-awful-idea/.

EU Delegation to Australia (2016), 'Australia and the EU: Economic relations'. Available at eeas.europa.eu/delegations/australia/610/ australia-and-eu_en\#Economic+relations, last accessed December 2016. 
European Commission (2013), 'Tenth Report on Potentially Trade Restrictive Measures, Identified in the Context of the Financial and Economic Crisis, 1 May 2012 - 31 May 2013', DG Trade.

European Commission (2014a), 'CETA - Summary of the Final Negotiating Results'. Available at trade.ec.europa.eu/doclib/docs/2014/ december/tradoc_152982.pdf.

European Commission (2014b), 'Eleventh Report on Potentially Trade Restrictive Measures, 1 June 2013 - 30 June 2014', DG Trade.

European Commission \& Government of Canada (2008), 'Assessing the Costs and Benefits of a Closer EU - Canada Economic Partnership: A Joint Study by the European Commission and the Government of Canada'. Available at trade.ec.europa.eu/doclib/docs/2008/october/ tradoc_141032.pdf.

European Union \& Government of Canada (2014), 'Consolidated CETA Text'. Available at trade.ec.europa.eu/doclib/docs/2014/september/ tradoc_152806.pdf.

Fafard, Patrick \& Patrick Leblond (2012), 'A Comprehensive Economic and Trade Agreement (CETA) between Canada and the European Union: Challenges for Canadian Federalism', Federal News 3(1), January (The Federal Idea: Montreal).

Fafard, Patrick \& Patrick Leblond (2013), 'Closing the deal: What role for the Provinces in the final stages of the CETA negotiations?' International Journal: Canada's Journal of Global Policy Analysis 68(4): 553-59. doi.org/10.1177/0020702013509319.

Government of Canada \& European Union (2014), 'Declaration by the Prime Minister of Canada and the Presidents of the European Council and European Commission'.

Government of Canada \& European Union (2016), 'Text of the Comprehensive Economic and Trade Agreement'. Available at www.international.gc.ca/trade-commerce/trade-agreements-accordscommerciaux/agr-acc/ceta-aecg/text-texte/toc-tdm.aspx?lang=eng.

Hage, Robert (2011), 'Changing Canada: Canada-European Union Free Trade', CETA Policy Brief, May (Canada-Europe Transatlantic Dialogue: Ottawa). Available at www.canada-europe-dialogue.ca. 
Hübner, Kurt (2010), 'CETA: Stumbling blocks in ongoing negotiations', CETA Policy Brief, May (Canada-Europe Transatlantic Dialogue: Ottawa). Available at www.canada-europe-dialogue.ca.

Kenyon, Donald \& Pierre van der Eng (2014), 'Defining the relationship between Australia and the European Union: Is the Framework Treaty enough?' Australian Journal of International Affairs 68(2): 225-42. doi.org/10.1080/10357718.2013.840558.

Messerlin, Patrick \& Sébastien Miroudet (2012a), 'EU Public Procurement Markets: How Open Are They?', Groupe d'Économie Mondiale Policy Brief, 10 August. Available at gem.sciences-po. $\mathrm{fr} /$ content/publications/pdf/Messerlin-Miroudot_EU_public_ procurement072012.pdf.

Messerlin, Patrick \& Sébastien Miroudot (2012b), 'Public Procurement Markets: Where Are We?' Vox CEPR's Policy Portal.

Robb, Andrew, MP Minister for Trade and Investment (2014), 'Government Sets Its Sights on New Trade Deal', Media Release, 14 November. Available at trademinister.gov.au/releases/Pages/2014/ ar_mr_141114a.aspx.

Sinclair, Scott, Stuart Trew \& Hadrian Mertins-Kirkwood, eds (2014), Making Sense of the CETA: an analysis of the final text of the CanadaEuropean Union Comprehensive Trade and Economic Agreement (Canadian Centre for Policy Alternatives: Ottawa), September.

UN Comtrade (2015a), 'Country Profile: Australia'. Available at comtrade.un.org/.

UN Comtrade (2015b), 'Country Profile: Canada'. Available at comtrade. un.org/.

World Bank (2016), 'Economy Rankings'. Available at www.doing business.org/rankings, last accessed December 2016.

WTO (World Trade Organization) (2015), Trade Policy Review, Report by the Secretariat: Australia, 21 July. Available at www.wto.org/ english/tratop_e/tpr_e/tp_rep_e.htm, last accessed December 2016. 
This text is taken from Australia, the European Union and the New Trade Agenda, edited by Annmarie Elijah, Don Kenyon, Karen Hussey and Pierre van der Eng, published 2017 by ANU Press, The Australian National University, Canberra, Australia. 